\title{
Local and regional contributions to fine particulate matter in the 18 cities of Sichuan Basin, southwestern China
}

\author{
Xue Qiao ${ }^{1,2,3}$, Hao Guo ${ }^{3}$, Ya Tang ${ }^{4}$, Pengfei Wang ${ }^{3}$, Wenye Deng ${ }^{5}$, Xing Zhao ${ }^{6}$, Jianlin $\mathrm{Hu}^{7}$, Qi Ying ${ }^{8}$, and \\ Hongliang Zhang ${ }^{3}$ \\ ${ }^{1}$ Institute of New Energy and Low-carbon Technology, Sichuan University, No. 24, South Section One, First Ring Road, \\ Chengdu, Sichuan 610065, China \\ ${ }^{2}$ Healthy Food Evaluation Research Center, Sichuan University, No. 24, South Section One, First Ring Road, Chengdu, \\ Sichuan 610065, China \\ ${ }^{3}$ Department of Civil and Environmental Engineering, Louisiana State University, Baton Rouge, LA 70803, USA \\ ${ }^{4}$ College of Architecture and Environment \& Healthy Food Evaluation Research Center, Sichuan University, \\ Chengdu 610065, China \\ ${ }^{5}$ Xinjiang Academy of Environmental Protection Science, Urumqi 830011, China \\ ${ }^{6}$ Department of Epidemiology and Biostatistics, West China School of Public Health, Sichuan University, No. 17, \\ Section 3, South Renmin Road, Chengdu, Sichuan 610041, China \\ ${ }^{7}$ Jiangsu Key Laboratory of Atmospheric Environment Monitoring and Pollution Control, Jiangsu Engineering Technology \\ Research Center of Environmental Cleaning Materials, Nanjing University of Information Science \& Technology, \\ Nanjing 210044, China \\ ${ }^{8}$ Zachry Department of Civil Engineering, Texas A\&M University, College Station, TX 77843, USA
}

Correspondence: Qi Ying (qying@civil.tamu.edu) and Hongliang Zhang (hlzhang@1su.edu)

Received: 19 November 2018 - Discussion started: 2 January 2019

Revised: 9 April 2019 - Accepted: 11 April 2019 - Published: 3 May 2019

\begin{abstract}
The Sichuan Basin (SCB) is one of the regions suffering from severe air pollution in China, but fewer studies have been conducted for this region than for the more developed regions in eastern and northern China. In this study, a source-oriented version of the Community Multiscale Air Quality (CMAQ) model was used to quantify contributions from nine regions to $\mathrm{PM}_{2.5}$ (i.e., particulate matter, $\mathrm{PM}$, with an aerodynamic diameter less than $2.5 \mu \mathrm{m}$ ) and its components in the 18 cities within the SCB in the winter (December 2014 to February 2015) and summer (June to August 2015). In the winter, citywide average $\mathrm{PM}_{2.5}$ concentrations are 45 $126 \mu \mathrm{g} \mathrm{m}^{-3}$, with $21 \%-51 \%$ and $39 \%-66 \%$ being due to local and nonlocal emissions, respectively. In the summer, $15 \%-45 \%$ and $25 \%-52 \%$ of citywide average $\mathrm{PM}_{2.5}$ (14$31 \mathrm{\mu g} \mathrm{m}^{-3}$ ) are due to local and nonlocal emissions, respectively. Compared to primary PM (PPM), the inter-region transport of secondary inorganic aerosols (SIA), including ammonia, nitrate, and sulfate ions $\left(\mathrm{NH}_{4}^{+}, \mathrm{NO}_{3}^{-}\right.$, and $\mathrm{SO}_{4}^{2-}$, respectively), and their gas-phase precursors are greater. The
\end{abstract}

region to the east of SCB (R7, including central and eastern China and others) is the largest contributor outside the $\mathrm{SCB}$, and it can contribute approximately $80 \%$ of $\mathrm{PM}_{2.5}$ in the eastern, northeastern, and southeastern rims of the SCB but only $10 \%$ in other SCB regions in both seasons. Under favorable transport conditions, regional transport of air pollutants from R7 could account for up to $35-100 \mu \mathrm{g} \mathrm{m}^{-3}$ of $\mathrm{PM}_{2.5}$ in each of the SCB cities in the winter. This study demonstrates that it is important to have joint emission control efforts among cities within the SCB and regions to the east in order to reduce $\mathrm{PM}_{2.5}$ concentrations and prevent high $\mathrm{PM}_{2.5}$ days for the entire basin.

\section{Introduction}

Particulate matter (PM) is one of the major air pollutants in China, including primary and secondary components. Primary PM (PPM) is directly released from emission sources, 
while secondary PM is formed from their precursors, such as sulfur dioxide $\left(\mathrm{SO}_{2}\right)$, nitrogen oxide $\left(\mathrm{NO}_{x}\right)$, and ammonia $\left(\mathrm{NH}_{3}\right)$. All of them are released from local sources or transported over a long distance (Ying et al., 2014; Zhao et al., 2018). The relative contributions of secondary components to total $\mathrm{PM}_{2.5}$ (PM with an aerodynamic diameter less than $2.5 \mu \mathrm{m}$ ) usually increase as $\mathrm{PM}_{2.5}$ concentration elevates in megacities (Huang et al., 2014; Qiao et al., 2018).

Air pollution in major economic centers in China, including the North China Plain (NCP), Yangtze River Delta (YRD), and Pearl River Delta (PRD), has been extensively studied in recent years. Regional transport of air pollutants has been identified as an important source of PM in the three regions, particularly the precursors of secondary PM (Zhang et al., 2013; X. Zhao et al., 2013; Ying et al., 2014; Jiang et al., 2015; Li et al., 2015; Wang et al., 2015; Zheng et al., 2015; Tang et al., 2016; Yang et al., 2018). Several urbanized areas in western China have also been suffering from air pollution due to rapid industrial and urban development, but fewer studies have been conducted compared to the NCP, YRD, and PRD. One such area is the Sichuan Basin (SCB), which covers an area about 0.22 million $\mathrm{km}^{2}$ and is home to more than 100 million residents in 18 cities, among which Chengdu and Chongqing are the largest two cities in western China (National Bureau of Statistics of China (NBSC), 2015; Table S1 in the Supplement). The SCB is topographically isolated, with mountains or plateaus on all sides. They are the Qinghai-Tibetan Plateau (QTP), Yunnan-Guizhou Plateau (YGP), Wu Mountains (WUM), and Daba Mountains (DBM) to the west, south, east, and north of the SCB, respectively. As a result of the basin topography, emissions released from the SCB tend to accumulate in the basin, causing severe air pollution (Ning et al., 2018a; Zhao et al., 2018). In addition, east and central China, which are to the east of the SCB, have considerable contributions to $\mathrm{PM}_{2.5}$ for the SCB. For example, Ying et al. (2014) predicted that central and east China had a combined contribution of $29.6 \%$ to the total mass of $\mathrm{NO}_{3}^{-}$and $\mathrm{SO}_{4}^{2-}$ for Chongqing in January 2009. Due to high emissions within the basin and deep basin landforms, annual average concentrations of $\mathrm{PM}_{2.5}$ in the SCB were similar to that of NCP and Central China (Fig. S1 in the Supplement). Annual $\mathrm{PM}_{2.5}$ measured in Chengdu and Chongqing in 2015 were 64 and $57 \mu \mathrm{g} \mathrm{m}^{-3}$, respectively, about 6 times the World Health Organization (WHO) guideline $\left(10 \mu \mathrm{g} \mathrm{m}^{-3}\right)$ (WHO, 2006; NBSC, 2015).

To design effective $\mathrm{PM}_{2.5}$ control strategies for the SCB, it is necessary to quantify the source contributions and interand intra-region transport of $\mathrm{PM}_{2.5}$ and its precursors within the SCB and its surrounding regions. There are many types of source apportionment methods, such as receptor-based models, air parcel trajectory models, remote-sensing, and chemical transport models (CTMs). Receptor-based models, such as the Positive Matrix Factorization model (PMF) (Paatero and Tapper, 1994; Qiu et al., 2019), the Chemical Mass Balance model (CMB) (Watson et al., 1990), and a local con- tribution model proposed by Zhao et al. (2019), are semiquantitative and cannot quantitatively determine the source contributions from an exact emission sector or a specific location. They also require a large number of monitoring data and can only resolve source contributions at the monitoring sites (Hopke, 2016). Remote-sensing and air parcel trajectory models, such as the Potential Source Contribution Function (PSCF) and the Hybrid Single Particle Lagrangian Integrated Trajectory Model (HYSPLIT) can only reflect the atmospheric dynamics, so they are not quantitative for source apportionment of secondary species (Begum et al., 2005; Uno et al., 2009; Stein et al., 2015; Liu et al., 2018; Wu et al., 2018). Compared to above methods, CTMs are more quantitative, as they can track the source contributions to both primary and secondary air pollutants from a specific region or sectorial source for studies at the local, regional, or global scale (Bove et al., 2014; Kim et al., 2015; Lelieveld et al., 2015; Itahashi et al., 2017; Shi et al., 2017). In CTMs, source contributions are quantified through two methods, namely, sensitivity analysis and tagged-tracer methods (Burr and Zhang, 2011). Sensitivity analysis such as the brute-force method is more suitable to estimate air quality changes due to emission perturbations, as emissions from certain sources would be eliminated or reduced in each simulation of sensitivity analysis (Burr and Zhang, 2011; Han et al., 2018; Huang et al., 2018). In the tagged-tracer method, source-tagged species are used to track air pollutants from specific emission regions and sectors, and they go through all of the nonlinear chemical and physical processes in the model, and thus this method is considered to provide more realistic evaluations of the contributions of different source sectors or source regions to the current level of air pollution under the current emission intensity (Wang et al., 2009; Burr and Zhang, 2011; Chen et al., 2017).

Transport of $\mathrm{PM}_{2.5}$ and its precursors has been studied for Chengdu, Chongqing, and the entire SCB region (Zhu et al., 2018). Based on in situ observations and the HYSPLIT model, studies have found that dust storms from northwestern China and biomass burning activities would cause high PM days in the two cities, particularly in spring (Zhao et al., 2010; Tao et al., 2013; Chen and Xie, 2014; Chen et al., 2015). Using the PSCF model, a study reported that the main potential sources of $\mathrm{PM}_{2.5}$ for Chengdu were from southeastern cities and the western margin of the SCB, in addition to local emissions from December 2013 to February 2014 (Liao et al., 2017). Based on the HYSPLIT and PSCF analyses, air pollution was determined mainly from the south during persistent extreme haze days in Chengdu from 6 to 16 January 2015 (Li et al., 2017). However, the aforementioned studies based on the HYSPLIT and PSCF models are not quantitative in terms of emission contributions. Their accuracy is also limited by the meteorological inputs that drive these models, which are often in very coarse resolutions $(0.5$ to $1.0^{\circ}$ ) that are not enough to accurately predict air pollutant transport within the $\mathrm{SCB}$, as meteorological conditions and 
pollutant concentrations may vary greatly within short distances (Shi et al., 2018). Also, previous country-level modeling studies did not have sufficient spatial resolution to properly quantify the transport among cities within the SCB.

Since both inter-regional transport within the cities in the basin and from outside the region can greatly affect $\mathrm{PM}_{2.5}$ concentrations in the $18 \mathrm{SCB}$ cities, systematically quantifying contributions from different regions to $\mathrm{PM}_{2.5}$ for all the 18 cities in the SCB is urgently needed as emission controls are further tightened to improve air quality in this region. In this study, an improved source-oriented community multiscale air quality (CMAQ) model was used to quantify the contributions from nine regions (five within the SCB and four outside) to $\mathrm{PM}_{2.5}$ and its components for the $18 \mathrm{SCB}$ cities. The assumption is that the transport of air pollutants is evident among the SCB cities and some cities on the rim of the SCB are greatly affected by emissions outside SCB. Therefore, the objectives of this study are to quantitatively determine (1) the inter-region transport of air pollutants emitted in the SCB and its contributions to $\mathrm{PM}_{2.5}$ in the $18 \mathrm{SCB}$ cities and (2) the contributions of emissions outside the basin to $\mathrm{PM}_{2.5}$ in the SCB. In this study, the percentage contributions and maximum mass contributions from each region to $\mathrm{PM}_{2.5}$ in each city are both presented to better understand the extent of air pollutant transport. We modeled $\mathrm{PM}_{2.5}$ and its source contributions for only two seasons, as $\mathrm{PM}_{2.5}$ concentrations in the SCB are highest and lowest in winter and summer, respectively (Ning et al., 2018a).

\section{Methods and materials}

\subsection{Model description}

The source-oriented CMAQ model used in this study is based on the CMAQ model version 5.0.1. The gas-phase and aerosol mechanisms are extended from the standard SAPRC99 photochemical mechanism and aerosol module version 6 (AERO6). This version of the source-oriented CMAQ is capable of simultaneously tracking both primary particulate matter (PPM) and secondary inorganic aerosols (SIA, including $\mathrm{NH}_{4}^{+}, \mathrm{NO}_{3}^{-}$, and $\mathrm{SO}_{4}^{2-}$ ) from multiple source sectors and regions. It unifies the two previous models individually developed for PPM (Hu et al., 2015) and SIA (Ying et al., 2014; Shi et al., 2017) into a single consistent model framework. For SIA, multiple source-tagged reactive species are introduced in both gas and particle phases to represent the same species originated from different source sectors or regions. The corresponding photochemical mechanisms, aerosol and cloud modules are expanded so that SIA and its precursors from different regions can be tracked separately throughout the model calculations. For example, $\mathrm{NO}_{2} \_\mathrm{S} 1$ and $\mathrm{NH}_{3} \_\mathrm{S} 2$ can be used to represent $\mathrm{NO}_{2}$ from region 1 and $\mathrm{NH}_{3}$ from region 2, respectively. After the photochemical mechanism is expanded, the source-tagged species are allowed to go through all processed to form $\left(\mathrm{NH}_{4} \_\mathrm{S} 2\right)\left(\mathrm{NO}_{3} \mathrm{~S}_{1}\right)$ based on additional reactions of $\mathrm{NO}_{2}+\mathrm{OH} \rightarrow \mathrm{HNO}_{3}$ and $\mathrm{NH}_{3}+$ $\mathrm{HNO}_{3} \rightarrow \mathrm{NH}_{4} \mathrm{NO}_{3}$. Thus, the contributions of region 1 to $\mathrm{NO}_{3}^{-}$and region 2 to $\mathrm{NH}_{4}^{+}$are quantified. For PPM, sourcetagged nonreactive tracers are added to track the total amount of PPM emitted from different source sectors and regions. SOA is included in the current model but its source contributions are not resolved.

\subsection{Model application}

The source-oriented CMAQ model was applied to quantify nine source region contributions to $\mathrm{PM}_{2.5}$ and its components (PPM and SIA) for the 18 cities in the winter (from December 2014 to February 2015) and summer (June to August 2015) using nested domain settings. The locations of the domains, the nine source regions, and the 18 cities of the SCB are shown in Fig. 1. The horizontal resolutions of the parent and nested domains are 36 and $12 \mathrm{~km}$, respectively. There are 18 vertical layers with an overall height of $20 \mathrm{~km}$ and the layer closest to the land surface is up to $35 \mathrm{~m}$. The geographical regions of emissions are classified into nine source regions. As Chengdu and Chongqing are the two largest cities in western China and within the SCB, we classified Chengdu, eastern Chongqing, and western Chongqing into three individual regions (R4, R5, and $\mathrm{R} 1$, respectively). Western Chongqing is well-urbanized and eastern Chongqing is mostly rural area. The five cities in the northeastern SCB (Bazhong, Dazhou, Guangyuan, Guang' an, and Nanchong) are grouped into R2, as they have relatively low anthropogenic emission densities compared to most of the other SCB cities and they are located in the upwind areas within the SCB (Qiao et al., 2019). The remaining SCB cities are grouped into R3. Sichuan Province, excluding those cities within the SCB, is R8, most of which is remote rural areas. R6 includes three provinces to the south of the SCB and R7 has the Chinese provinces to the east and northeast of the SCB. R9 includes the other jurisdictions to the west of the SCB, including Xinjiang, Qinghai, Gansu, Tibet, and other countries.

Meteorological inputs were generated using the Weather Research and Forecasting (WRF) model version 3.9 based on the 6-hourly FNL (Final) Operational Global Analysis data from the National Center for Atmospheric Research (NCAR) with a spatial resolution of $1.0^{\circ} \times 1.0^{\circ}$ (https://rda.ucar.edu/ datasets/ds083.2/, last access: 27 April 2019). The anthropogenic emission inventory used was the Emission Database for Global Atmospheric Research (EDGAR) version 4.3.1 for the year of 2012 (Crippa et al., 2018). The inventory was directly used for the model year of 2014-2015, as no reliable sources for emission changes in the SCB are available. The monthly EDGAR inventories have a spatial resolution of $0.1^{\circ} \times 0.1^{\circ}(\sim 10 \mathrm{~km} \times 10 \mathrm{~km})$ and were re-projected to the model domains using the Spatial Allocator (https://www. cmascenter.org/sa-tools/, last access: 27 April 2019). Tem- 

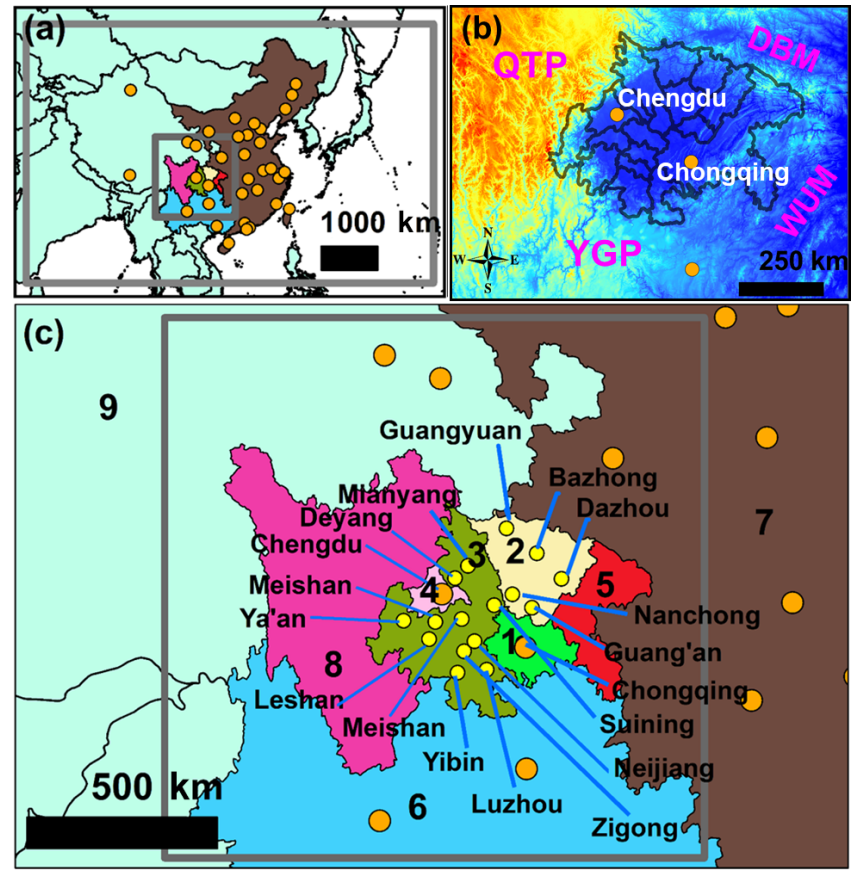

Figure 1. (a) Locations of the 12 and $36 \mathrm{~km}$ domains (grey rectangles) and the locations of provincial capitals and municipalities (orange circles), (b) terrain within and surrounding the 18 cities of the SCB (black line), and (c) locations of region categories 1-9 and the prefecture-level cities (yellow circles). Regions 1-5 are the cities within the SCB. Regions 1, 4, and 5 are western Chongqing, Chengdu, and eastern Chongqing, respectively. The city center of Chongqing is located in western Chongqing. Region 8 is the area of Sichuan Province, excluding those cities in the SCB. QTP, Qinghai-Tibetan Plateau; YGP, Yunnan-Guizhou Plateau; DBM, Daba Mountains; WUM, Wu Mountains.

poral profiles specific to sources were used to allocate the monthly emission rates to hourly values for CMAQ modeling (Wang et al., 2010). The EDGAR inventory includes carbon monoxide (CO), $\mathrm{NO}_{x}, \mathrm{SO}_{2}, \mathrm{NH}_{3}$, non-methane volatile organic compounds (NMVOCs), $\mathrm{PM}_{2.5}, \mathrm{PM}_{10}$ (PM with an aerodynamic diameter less than $10 \mu \mathrm{m})$, elemental carbon (EC), and organic carbon (OC) from various sources. Emission sources are grouped into six categories: energy, industries, residential activities, on-road transportation, off-road transportation, and agriculture. In addition to these six anthropogenic sources, contributions of biogenic sources were also determined using emissions generated by the Emissions of Gases and Aerosols from Nature (MEGAN) model version 2.1 (Guenther et al., 2012). The emissions from open burning were estimated based on the Fire Inventory from the National Center for Atmospheric Research (NCAR FINN) (Wiedinmyer et al., 2011). Contributions of windblown dust and sea salt emissions were determined based on in-line generated emissions during CMAQ simulations. It should be noted that the uncertainties in emission inventories potentially lead to uncertainties in the contributions.
The initial and boundary conditions (ICs and BCs, respectively) for the $36 \mathrm{~km}$ domain were based on CMAQ default profiles, and those for the $12 \mathrm{~km}$ domain were generated using the CMAQ outputs from the $36 \mathrm{~km}$ simulations. More details about the setup and configuration of the WRF/CMAQ modeling system can be found for China in a previous publication (Kang et al., 2016).

\section{Results and discussion}

\subsection{Model performance}

The model performance on meteorological parameters and $24 \mathrm{~h} \mathrm{PM}_{2.5}$ in the $12 \mathrm{~km}$ domain for the two seasons has been evaluated in a companion paper (Qiao et al., 2019) and is briefly summarized here (Fig. S2). As the predictions on wind speed (WS) and wind direction (WD) are important in modeling air pollutant transport (Zhao et al., 2009), the WRF model performance for WS, WD, ambient air temperature $(T)$, and relative humidity (RH) were evaluated by using hourly observations at China's national meteorological stations and the observation data that were downloaded from the National Climate Data Center (NCDC; ftp://ftp.ncdc.noaa. gov/pub/data/noaa/, last access: 20 June 2018). The mean biases (MBs) of predicted RH $(-10.8 \%$ to $-1.1 \%)$ and $T$ $\left(-0.9\right.$ to $\left.-0.1{ }^{\circ} \mathrm{C}\right)$ in each month are comparable to other studies in China (Wang et al., 2010, 2014; B. Zhao et al., 2013). The MB of WD in each month $\left(-5\right.$ to $\left.6^{\circ}\right)$ meet the benchmark of $< \pm 10^{\circ}$ suggested by Emery et al. (2001). Although the MB of WS in each month $\left(0.5\right.$ to $\left.1.1 \mathrm{~m} \mathrm{~s}^{-1}\right)$ does not meet the benchmark of $< \pm 0.5 \mathrm{~m} \mathrm{~s}^{-1}$, the gross errors (GEs: $1.4-1.9 \mathrm{~m} \mathrm{~s}^{-1}$ ) are within the benchmark of $2.0 \mathrm{~m} \mathrm{~s}^{-1}$. For $24 \mathrm{~h} \mathrm{PM}_{2.5}$ concentrations, the statistical metrics of model performance are generally within the criteria recommended by Emery et al. (2017) for regulatory applications, with only a few cities exceeding the normalized mean bias (NMB) criteria of $< \pm 30 \%$ in the winter (Chongqing $42 \%$, Guangyuan $41 \%$, Mianyang $37 \%$, Meishan $31 \%$, Ziyang $48 \%$ ) and in the summer (Dazhou -39\%) (Fig. S2). The $24 \mathrm{~h} \mathrm{PM}_{2.5}$ predictions meet the goals of normalized mean error (NME $\pm 35 \%$ ), fractional bias ( $\mathrm{FB} \pm 30 \%$ ), and fractional error $(\mathrm{FE} \pm 50 \%)$ in all the cities in both seasons, except for the NME of Ziyang (58\%) in the winter. The predictions of major $\mathrm{PM}_{2.5}$ components (including $\mathrm{OC}, \mathrm{EC}, \mathrm{NH}_{4}^{+}$, $\mathrm{NO}_{3}^{-}$, and $\mathrm{SO}_{4}^{2-}$ ) in Chengdu and Chongqing are comparable with observations, and both predictions and observations suggest that OC and SIA are the largest contributors to $\mathrm{PM}_{2.5}$ in summer and winter, with combined contributions of about $70 \%$ (Qiao et al., 2019). 


\subsection{Seasonal average contributions}

\subsubsection{Source contributions at the city centers}

In each city, there are 4 to 17 national air quality stations (NAQs), and almost all the NAQs are located in the urban areas, where population densities are higher. Thus, coordinates of the NAQs in the urban area of a given city were averaged to define the city center in order to understand $\mathrm{PM}_{2.5}$ concentrations and its sources for the most-populated region of each city. The predicted $\mathrm{PM}_{2.5}$ concentrations and sourceregion contributions at the $18 \mathrm{SCB}$ city centers are presented in Table 1 for winter and Table S2 for summer. In all the city centers, the predicted $\mathrm{PM}_{2.5}$ concentrations are much higher in the winter $\left(60-191 \mu \mathrm{g} \mathrm{m}^{-3}\right)$ than in the summer $\left(14-64 \mu \mathrm{g} \mathrm{m}^{-3}\right)$. The city centers are considerably affected by both local and regional emissions in both seasons. Emissions within the SCB are the major contributor to $\mathrm{PM}_{2.5}$ in Chengdu and Chongqing in both seasons $(\sim 80 \%)$ and emissions outside the SCB contribute approximately $7 \%-$ $15 \%$. Among the regions within the SCB, local emissions (i.e., emissions from the region where the city center is located) are the largest contributor to $\mathrm{PM}_{2.5}$ in Chongqing and Chengdu in both seasons (about $70 \%$ and $58 \%$, respectively). However, emissions from R3 (i.e., the 11 cities in the northwestern, western, and southwestern SCB) also have considerable contribution in Chengdu ( 20\% and $14 \%$ in the winter and summer, respectively). For the R3 cities, the contributions of emissions within the SCB (64\%-83\%) are also larger than that from outside the SCB (8\%-26\%) in both seasons. Local emissions are the largest contributor for R3 cities (40\%-60\%), except that Suining has only 13\% due to its local region. The low local contribution in Suining might be because it is less economically developed compared to other cities, except for Bazhong, Guangyuan, and Ya'an, as suggested by the 2015 gross domestic product (GDP; Table S1). For the five cities in the northern SCB (R2), emissions within the SCB account for $40 \%-70 \%$ in both seasons, including $37 \%-57 \%$ from local emissions. Emissions outside the SCB also have large contributions to the R2 cities (21\%-36\% and $17 \%-28 \%$ in the winter and summer, respectively), as R2 is located in one of the regions where winds from R7 intrude the basin (Fig. 2a). In the winter, contributions from SOA and others (including IC, BC, windblown dust, and sea salt) are less than $8 \%$ each. In the summer, SOA and others each contribute 9\%-28\% and less than $10 \%$, respectively, but the SOA contributions larger than $15 \%$ are found only in the city centers where summer $\mathrm{PM}_{2.5}$ concentrations are less than $30 \mu \mathrm{g} \mathrm{m}^{-3}$. In summary, local emissions are the largest contributor for all the city centers in both seasons, except for Suining. The nonlocal contributions for the city centers are in the range of $25 \%-52 \%$ in the winter (except for $75 \%$ in Suining) and of $14 \%-40 \%$ in the summer (except for $61 \%$ in Suining) and emissions outside the SCB account for 7\%-36\% in both seasons.

\subsubsection{Spatial variations and citywide area-weighted averages}

The spatial variations in source-region contributions to $\mathrm{PM}_{2.5}$ in the winter and summer are presented in Figs. 2 and 3, respectively. In both seasons, local emissions are generally the largest contributor in each city, except that R7 has contributions similar to or larger than those of local emissions for most regions in eastern Chongqing (R5) and R2. Specifically, the contributions from $\mathrm{R} 7$ to $\mathrm{PM}_{2.5}$ in R2 and R5 are approximately $20 \%-80 \%$ in the winter and $20 \%-60 \%$ in the summer. R7 also has contributions larger than $20 \%$ for a few areas in R3. The regions of R6, R8, and R9 outside the $\mathrm{SCB}$ each has contributions of $<5 \%$ across the basin, except for some very limited areas in the western and southern rims of the SCB. The contributions from R6, R8, and R9 are low because these areas are less urbanized and industrialized. In addition, the mountains to the west and south of the SCB also prevent the transport of air pollutants from these regions into the SCB (Figs. 1c, 2a, and 3a). In summary, R7 is the sole non-SCB region that can have $>20 \%$ contributions to $\mathrm{PM}_{2.5}$ in the $\mathrm{SCB}$, and its impact decreases from the northeast, east, and southeast of others in the basin.

As shown in Figs. 2 and 3, $\mathrm{PM}_{2.5}$ concentrations and their source contributions from a given region may vary greatly within a city in both seasons. For example, about 20\%-80\% of $\mathrm{PM}_{2.5}$ across Chengdu (R4) and western Chongqing (R1) are due to local emissions in each season, and higher $\mathrm{PM}_{2.5}$ concentrations are generally related to higher local contributions. For the downwind regions of Chengdu and western Chongqing, they receive considerable contributions from the two megacities. For example, over half of Meishan and Ya'an, which are downwind of Chengdu, have 20\%-40\% and $20 \%-60 \%$ of $\mathrm{PM}_{2.5}$ concentrations due to Chengdu in the winter, respectively. In the two seasons, western Chongqing contributes about $10 \%-40 \%$ of $\mathrm{PM}_{2.5}$ concentrations in its neighboring cities, except that most of eastern Chongqing (R5) is not affected by emissions from western Chongqing, as R5 is upwind of western Chongqing (Fig. 2a). Because of the large spatial variations of $\mathrm{PM}_{2.5}$ and its source contributions in the basin, we further calculated their citywide area-weighted averages (Table 2). In the winter, the citywide average $\mathrm{PM}_{2.5}$ concentrations in Chengdu and urban Chongqing are 99 and $110 \mu \mathrm{g} \mathrm{m}^{-3}$, with only $38 \%$ and $47 \%$ due to local emissions, respectively. Nonlocal emissions also have high contributions in other SCB cities, with citywide averages of $39 \%-66 \%$ and $25 \%-52 \%$ in the winter and summer, respectively. The above suggests the importance of regional emission control for reducing $\mathrm{PM}_{2.5}$ concentrations for the entire basin.

\subsubsection{Differences in PPM and SIA}

The transport distances of PPM, $\mathrm{NH}_{4}^{+}, \mathrm{NO}_{3}^{-}$, and $\mathrm{SO}_{4}^{2-}$ might be different because of the differences in chemical 
Table 1. Predicted source-region contributions to $\mathrm{PM}_{2.5}$ in the $18 \mathrm{SCB}$ city centers in the winter. The data in bold font show the contributions due to local emissions, emissions within SCB, or emissions outside SCB.

\begin{tabular}{|c|c|c|c|c|c|c|c|c|c|c|c|c|c|c|c|c|}
\hline \multirow[t]{2}{*}{ Region ID } & \multirow[t]{2}{*}{ City } & \multirow{2}{*}{$\begin{array}{r}\mathrm{PM}_{2.5} \\
\left(\mu \mathrm{g} \mathrm{m}^{-3}\right)\end{array}$} & \multicolumn{14}{|c|}{ Contributions from each region, SOA, and others ${ }^{\mathrm{a}}(\%)$} \\
\hline & & & $\mathrm{R} 1$ & $\mathrm{R} 2$ & R3 & $\mathrm{R} 4$ & R5 & $\begin{array}{r}\text { Within } \\
\text { SCB }\end{array}$ & R6 & R7 & $\mathrm{R} 8$ & R9 & $\begin{array}{r}\text { Outside } \\
\text { SCB }\end{array}$ & SOA & Others & $\begin{array}{l}\text { Non- } \\
\text { local }^{b}\end{array}$ \\
\hline $\mathrm{R} 1$ & Chongqing $^{c}$ & 191 & 67.7 & 4.5 & 3.7 & 0.4 & 1.8 & 78.1 & 2.7 & 11.1 & 0.1 & 0.9 & 14.8 & 3.9 & 3.3 & 25.2 \\
\hline \multirow[t]{5}{*}{$\mathrm{R} 2$} & Bazhong & 65 & 2.0 & 42.6 & 2.8 & 1.2 & 2.9 & 51.5 & 1.7 & 31.9 & 0.1 & 2.7 & 36.4 & 6.9 & 5.1 & 45.3 \\
\hline & Dazhou & 89 & 2.4 & 47.3 & 1.7 & 0.5 & 7.5 & 59.4 & 1.5 & 27 & 0.1 & 1.6 & 30.2 & 6.0 & 4.3 & 42.3 \\
\hline & Guang'an & 109 & 8.9 & 50.4 & 2.0 & 0.5 & 5.4 & 67.2 & 2.3 & 19.6 & 0.1 & 1.4 & 23.4 & 5.8 & 3.5 & 40.2 \\
\hline & Guangyuan & 60 & 2.3 & 45.5 & 5.2 & 1.8 & 1.7 & 56.5 & 1.3 & 25.5 & 0.1 & 4.2 & 31.1 & 6.5 & 5.8 & 42.1 \\
\hline & Nanchong & 120 & 6.1 & 56.5 & 3.2 & 0.6 & 3.1 & 69.5 & 1.8 & 18.1 & 0.1 & 1.3 & 21.3 & 5.7 & 3.4 & 34.3 \\
\hline \multirow[t]{11}{*}{ R3 } & Deyang & 143 & 2.7 & 4.6 & 58.0 & 14.5 & 0.8 & 80.6 & 0.8 & 9.4 & 0.1 & 1.6 & 11.9 & 4.2 & 3.4 & 34.5 \\
\hline & Leshan & 125 & 2.9 & 3.1 & 58.7 & 15.1 & 0.6 & 80.4 & 1.2 & 8.2 & 0.1 & 1.2 & 10.7 & 5.7 & 3.0 & 32.4 \\
\hline & Luzhou & 149 & 13.9 & 4.8 & 53.9 & 1.8 & 1.2 & 75.6 & 3.8 & 11.2 & 0.1 & 1.0 & 16.1 & 5.4 & 2.9 & 37.8 \\
\hline & Meishan & 153 & 2.5 & 3.1 & 40.2 & 36.3 & 0.6 & 82.7 & 0.9 & 7.7 & 0.1 & 1.1 & 9.8 & 4.6 & 2.9 & 52.3 \\
\hline & Mianyang & 114 & 2.7 & 6.8 & 60.3 & 4.8 & 1.1 & 75.7 & 0.9 & 12.4 & 0.1 & 2.2 & 15.6 & 4.9 & 3.8 & 31.0 \\
\hline & Neijiang & 140 & 11.3 & 7.6 & 51.9 & 2.8 & 1.3 & 74.9 & 2.4 & 12.7 & 0.1 & 1.1 & 16.3 & 5.6 & 3.1 & 39.3 \\
\hline & Suining & 100 & 11.7 & 33.5 & 14.4 & 1.1 & 3.2 & 63.9 & 2.6 & 21.4 & 0.1 & 1.7 & 25.8 & 6.8 & 3.6 & 75.3 \\
\hline & Ya'an & 79 & 3.2 & 3.6 & 45.9 & 20.1 & 0.7 & 73.5 & 1.4 & 11.0 & 0.3 & 2.3 & 15.0 & 7.6 & 3.8 & 42.6 \\
\hline & Yibin & 134 & 6.8 & 4.1 & 60.1 & 5.5 & 0.9 & 77.4 & 2.8 & 9.7 & 0.1 & 1.1 & 13.7 & 6.0 & 3.0 & 31.0 \\
\hline & Zigong & 145 & 8.9 & 6.0 & 57.1 & 3.2 & 1.1 & 76.3 & 2.4 & 11.4 & 0.1 & 1.1 & 15.0 & 5.5 & 3.3 & 34.2 \\
\hline & Ziyang & 131 & 5.8 & 7.3 & 54.0 & 7.1 & 1.2 & 75.4 & 1.7 & 12.6 & 0.1 & 1.4 & 15.8 & 5.6 & 3.2 & 37.2 \\
\hline $\mathrm{R} 4$ & Chengdu & 144 & 2.2 & 3.5 & 20.4 & 55.2 & 0.6 & 81.9 & 0.8 & 8.2 & 0.1 & 1.4 & 10.5 & 4.2 & 3.5 & 37.2 \\
\hline
\end{tabular}

${ }^{a}$ Others includes initial and boundary conditions, windblown dust, and sea salt. ${ }^{b}$ Nonlocal $=$ within SCB + outside SCB - local. ${ }^{\mathrm{c}}$ The city center of Chongqing.
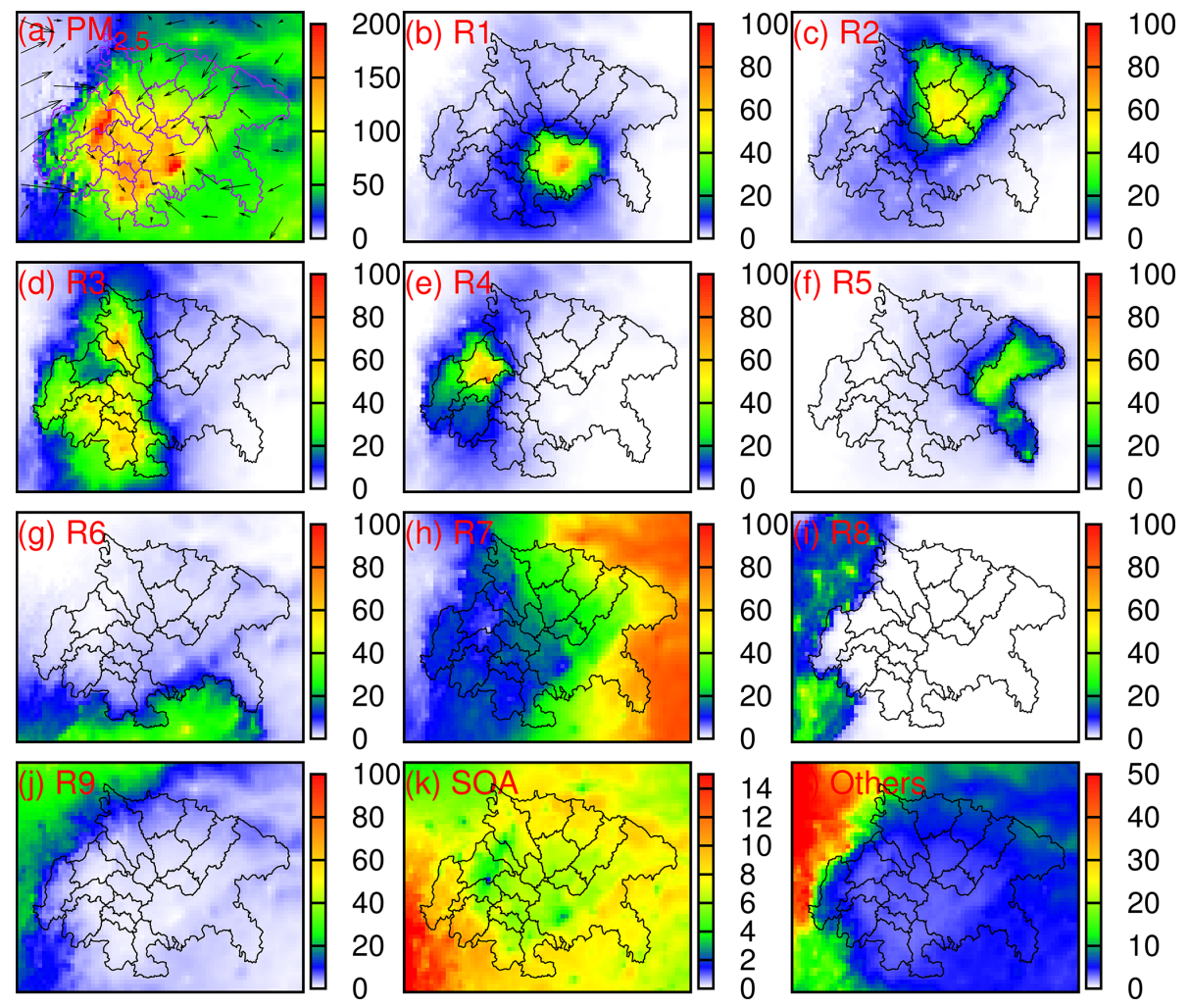

Figure 2. (a) Spatial distributions of predicted $\mathrm{PM}_{2.5}$ concentrations $\left(\mu \mathrm{g} \mathrm{m}{ }^{-3}\right)$ and $(\mathbf{b}-\mathbf{l})$ source-region contributions to $\mathrm{PM}_{2.5}(\%)$ in the winter. Others includes IC, BC, windblown dust, and sea salt. Black arrows in (a) are wind vectors. 
Table 2. Predicted citywide area-weighted average $\mathrm{PM}_{2.5}$ concentrations and source-region contributions in the $18 \mathrm{SCB}$ cities in the winter and summer.

\begin{tabular}{|c|c|c|c|c|c|c|c|c|c|c|c|}
\hline \multirow{3}{*}{$\begin{array}{l}\text { Region } \\
\text { ID }\end{array}$} & \multirow{3}{*}{$\begin{array}{r}\text { No. of } \\
\text { grid } \\
\text { cells }\end{array}$} & \multirow{3}{*}{$\begin{array}{r}\text { Total } \\
\text { area } \\
\left(\mathrm{km}^{2}\right)\end{array}$} & \multirow[t]{3}{*}{ City } & \multirow{3}{*}{$\begin{array}{r}\text { No. of } \\
\text { grid } \\
\text { cells }\end{array}$} & \multirow{3}{*}{$\begin{array}{r}\text { Total } \\
\text { area } \\
\left(\mathrm{km}^{2}\right)\end{array}$} & \multicolumn{3}{|c|}{ Winter } & \multicolumn{3}{|c|}{ Summer } \\
\hline & & & & & & \multirow{2}{*}{$\begin{array}{r}\mathrm{PM}_{2.5} \\
\left(\mu \mathrm{g} \mathrm{m}^{-3}\right)\end{array}$} & \multicolumn{2}{|c|}{ Contributions (\%) } & \multirow{2}{*}{$\begin{array}{r}\mathrm{PM}_{2.5} \\
\left(\mu \mathrm{g} \mathrm{m}^{-3}\right)\end{array}$} & \multicolumn{2}{|c|}{ Contributions (\%) } \\
\hline & & & & & & & Local & Nonlocal* $^{*}$ & & Local & Nonlocal * \\
\hline $\mathrm{R} 1$ & 248 & 28011 & Western Chongqing & 248 & 28011 & 99 & 37.8 & 52.1 & 27 & 36.8 & 36.0 \\
\hline \multirow[t]{5}{*}{$\mathrm{R} 2$} & 543 & 56265 & Bazhong & 106 & 10734 & 51 & 27.9 & 58.2 & 14 & 19.3 & 43.6 \\
\hline & & & Dazhou & 139 & 14689 & 64 & 29.1 & 58.6 & 16 & 21.6 & 45.7 \\
\hline & & & Guang'an & 60 & 5618 & 100 & 40.6 & 49.5 & 23 & 32.3 & 40.3 \\
\hline & & & Guangyuan & 133 & 14182 & 50 & 28.3 & 57.1 & 13 & 23.4 & 40.5 \\
\hline & & & Nanchong & 105 & 11042 & 89 & 47.9 & 41.4 & 20 & 36.3 & 34.1 \\
\hline \multirow[t]{11}{*}{$\mathrm{R} 3$} & 998 & 98185 & Deyang & 59 & 5346 & 101 & 49.9 & 40.2 & 25 & 44.5 & 32.8 \\
\hline & & & Leshan & 107 & 11599 & 81 & 42.5 & 44.4 & 14 & 35.0 & 29.7 \\
\hline & & & Luzhou & 112 & 10758 & 92 & 35.3 & 53.8 & 20 & 25.6 & 43.7 \\
\hline & & & Meishan & 74 & 6570 & 120 & 42.6 & 47.7 & 26 & 36.7 & 35.8 \\
\hline & & & Mianyang & 171 & 18012 & 59 & 36.8 & 49.2 & 15 & 32.9 & 36.7 \\
\hline & & & Neijiang & 58 & 4859 & 122 & 45.8 & 44.8 & 29 & 40.8 & 34.7 \\
\hline & & & Suining & 50 & 4743 & 104 & 30.3 & 59.7 & 23 & 25.4 & 48.4 \\
\hline & & & Ya'an & 131 & 13493 & 45 & 34.5 & 49.2 & 6 & 27.9 & 35.1 \\
\hline & & & Yibin & 117 & 11827 & 101 & 50.1 & 39.1 & 21 & 43.3 & 24.9 \\
\hline & & & Zigong & 45 & 3935 & 126 & 51.3 & 39.4 & 30 & 47.3 & 26.9 \\
\hline & & & Ziyang & 74 & 7042 & 115 & 40.3 & 50.2 & 25 & 32.6 & 41.9 \\
\hline $\mathrm{R} 4$ & 105 & 10753 & Chengdu & 105 & 10753 & 110 & 46.5 & 44.1 & 31 & 44.6 & 33.0 \\
\hline R5 & 390 & 44371 & Eastern Chongqing & 390 & 44371 & 54 & 21.0 & 66.0 & 15 & 14.7 & 52.1 \\
\hline
\end{tabular}

* Nonlocal $=100 \%$-local-SOA-others; Others includes initial and boundary conditions, windblown dust, and sea salt.

and physical processes that affect their concentrations in the atmosphere (Ying et al., 2014; Hu et al., 2015). This leads to significant differences in their regional distributions and thus requires different control strategies. From the sourceregion contributions to PPM and SIA for each city center shown in Fig. 4, it is obvious that the regional transport of SIA is more significant than that of PPM. In the city centers of Chengdu and Chongqing, 55\%-65\% of PPM and $25 \%-$ $45 \%$ of SIA are due to local emissions in the two seasons. In the city centers of R2, PPM is also more from local emissions $(65 \%-80 \%)$ than SIA is $(25 \%-45 \%)$ in both seasons. Similarly, local emissions have larger contributions to PPM $(50 \%-85 \%)$ than to SIA $(34 \%-50 \%)$ in all the city centers of R3 except for Suining, which is not significantly affected by local emissions. The spatial distributions of source-region contributions to PPM and SIA also indicate more significant transport of SIA (Figs. S3-6) than PPM. For example, R3 contributes to $>20 \%$ of SIA across all of Chengdu, but only half the areas of Chengdu are about equally affected (>20\%) by R3 for PPM. From the north to south in R2, the contributions from R7 to PPM decrease from $\sim 55 \%$ to $\sim 10 \%$, while the contributions of $\mathrm{R} 7$ to SIA decrease from $\sim 75 \%$ to $\sim 20 \%$. The contributions to $\mathrm{NH}_{4}^{+}, \mathrm{NO}_{3}^{-}$, and $\mathrm{SO}_{4}^{2-}$ in each city center from local emissions and emissions within and outside SCB are further analyzed (Tables S3 and S4). In each city center, concentrations of $\mathrm{SO}_{4}^{2-}(3.8-12.6$ and $12-$
$41 \mu \mathrm{g} \mathrm{m}^{-3}$ ) are much higher than that of $\mathrm{NH}_{4}^{+}$(1.4-4.0 and $\left.6.0-17.0 \mu \mathrm{g} \mathrm{m}^{-3}\right)$ and $\mathrm{NO}_{3}^{-}\left(0.3-2.4\right.$ and $\left.6-20 \mu \mathrm{g} \mathrm{m}^{-3}\right)$ in the summer and winter, respectively. Also, the transport of $\mathrm{SO}_{4}^{2-}$ and its precursor is greater than the other two ions, as the percentage contributions from emissions outside the SCB to $\mathrm{SO}_{4}^{2-}$ is higher than that to $\mathrm{NH}_{4}^{+}$and $\mathrm{NO}_{3}^{-}$in each city center. In both seasons, emissions outside SCB contribute $<25 \%$ of $\mathrm{NH}_{4}^{+}$in the city centers, except for Chongqing (26\%) in the summer and Bazhong (36\%) and Guangyuan (33\%) in the winter. As for $\mathrm{NO}_{3}^{-}$, emissions outside SCB also contribute $<25 \%$ in the city centers in both seasons, except for Bazhong (49\%), Dazhou (34\%), and Guangyuan $(25 \%)$ in the summer and all the cities of R2 $(27 \%-57 \%)$ in the winter. In the two seasons, emissions outside SCB account for $22 \%-33 \%$ of $\mathrm{SO}_{4}^{2-}$ in Chengdu and Chongqing, while they contribute $52 \%-70 \%$ of $\mathrm{SO}_{4}^{2-}$ for the $\mathrm{R} 2$ cities. For the $\mathrm{R} 3$ cities, emissions outside SCB account for $25 \%-53 \%$ of $\mathrm{SO}_{4}^{2-}$ in the city centers in both seasons, except for Meishan $(21 \%)$ in the winter. All the above suggest that it would be more efficient to control the SIA (particularly $\mathrm{SO}_{4}^{2-}$ ) and its precursors than PPM in order to reduce the transport of air pollutants within and into the basin. 

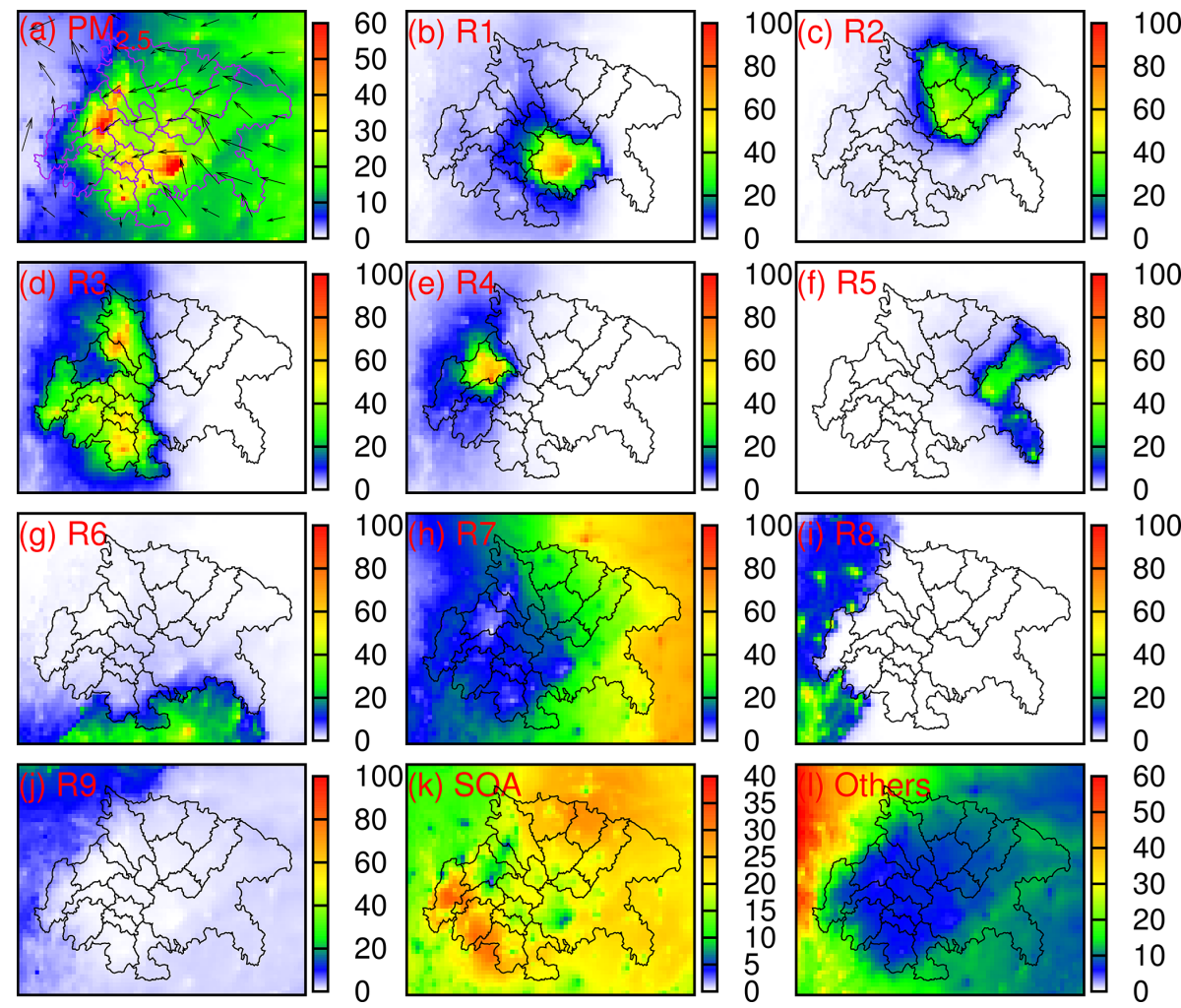

Figure 3. (a) Spatial distributions of predicted $\mathrm{PM}_{2.5}$ concentrations $\left(\mu \mathrm{g} \mathrm{m}^{-3}\right)$ and $(\mathbf{b}-\mathbf{l})$ the source-region contributions to $\mathrm{PM} 2.5(\%)$ in the summer. Others includes IC, BC, windblown dust, and sea salt.

Table 3. Predicted maximum daily contribution from a given region (MDCs) in the SCB city center and the corresponding $\mathrm{PM}_{2.5}$ concentrations in the city center on the same day. Only winter data are included in this table. The units are $\mu \mathrm{g} \mathrm{m}^{-3}$. The numbers in the bold present the contributions due to local emissions or that from R7.

\begin{tabular}{|c|c|c|c|c|c|c|c|c|c|c|c|c|}
\hline \multirow[t]{3}{*}{ Region ID } & \multirow[t]{3}{*}{ Cities } & \multicolumn{11}{|c|}{ MDCs (total $\mathrm{PM}_{2.5}$ concentrations) } \\
\hline & & \multicolumn{5}{|c|}{ Within SCB } & \multicolumn{4}{|c|}{ Outside SCB } & \multirow[t]{2}{*}{ SOA } & \multirow[t]{2}{*}{ Others $^{\mathrm{a}}$} \\
\hline & & $\mathrm{R} 1$ & $\mathrm{R} 2$ & $\mathrm{R} 3$ & R4 & R5 & R6 & $\mathrm{R} 7$ & $\mathrm{R} 8$ & R9 & & \\
\hline $\mathrm{R} 1$ & Chongqing $^{\mathrm{b}}$ & $291(353)$ & $54(414)$ & $48(294)$ & $16(302)$ & $15(143)$ & $22(290)$ & $99(200)$ & $1(182)$ & $8(212)$ & $12(160)$ & $12(294)$ \\
\hline \multirow[t]{5}{*}{$\mathrm{R} 2$} & Bazhong & $8(160)$ & 83 (139) & $23(160)$ & $18(160)$ & $7(64)$ & $14(68)$ & 73 (109) & $0(140)$ & $6(90)$ & $14(327)$ & $11(34)$ \\
\hline & Dazhou & $46(219)$ & $123(216)$ & $16(171)$ & $6(171)$ & 34 (219) & $12(77)$ & $79(190)$ & $0(173)$ & $5(54)$ & $18(367)$ & $8(54)$ \\
\hline & Guang'an & 72 (159) & $129(205)$ & $31(180)$ & $10(180)$ & $22(225)$ & $14(102)$ & $76(165)$ & $0(234)$ & $5(129)$ & $16(219)$ & $7(75)$ \\
\hline & Guangyuan & $11(122)$ & $60(107)$ & 35 (122) & $15(122)$ & $4(56)$ & $10(86)$ & $62(100)$ & $0(91)$ & $11(46)$ & $16(226)$ & $10(25)$ \\
\hline & Nanchong & $58(180)$ & $152(242)$ & $50(200)$ & $12(243)$ & $18(238)$ & $13(141)$ & $78(166)$ & $0(177)$ & $5(136)$ & $17(178)$ & $10(71)$ \\
\hline \multirow[t]{11}{*}{ R3 } & Deyang & $32(226)$ & $30(257)$ & $170(296)$ & $147(288)$ & $4(257)$ & $14(215)$ & 70 (132) & $0(215)$ & $9(137)$ & $13(91)$ & $10(67)$ \\
\hline & Leshan & $15(270)$ & 15 (166) & $163(270)$ & $57(222)$ & $4(166)$ & $10(222)$ & $47(122)$ & $1(108)$ & $5(118)$ & $15(222)$ & $9(105)$ \\
\hline & Luzhou & $115(245)$ & 33 (207) & $211(261)$ & $21(240)$ & $10(207)$ & 18 (259) & $71(272)$ & 1 (192) & $6(90)$ & 17 (307) & $10(182)$ \\
\hline & Meishan & 17 (189) & $22(379)$ & 155 (379) & $138(235)$ & $4(176)$ & $11(263)$ & $54(263)$ & $1(379)$ & $5(80)$ & 15 (164) & $9(100)$ \\
\hline & Mianyang & $24(209)$ & $30(170)$ & $219(294)$ & $67(305)$ & $6(168)$ & $11(144)$ & 70 (112) & $0(337)$ & $9(86)$ & $16(294)$ & $11(46)$ \\
\hline & Neijiang & $93(214)$ & 39 (168) & $161(205)$ & 49 (309) & $6(168)$ & $17(165)$ & 79 (198) & $1(192)$ & 5 (198) & $19(181)$ & $9(164)$ \\
\hline & Suining & 75 (183) & $110(242)$ & $105(186)$ & $25(225)$ & $14(210)$ & $17(151)$ & 83 (167) & 0 (154) & $5(79)$ & 17 (198) & $10(41)$ \\
\hline & Ya'an & $14(126)$ & $17(205)$ & $79(170)$ & 88 (234) & $3(205)$ & $8(170)$ & 35 (205) & $1(123)$ & $6(40)$ & 15 (189) & $9(43)$ \\
\hline & Yibin & $74(283)$ & $21(162)$ & $160(217)$ & 45 (164) & $5(236)$ & $16(188)$ & $58(166)$ & $1(122)$ & 4 (147) & $14(170)$ & $9(127)$ \\
\hline & Zigong & $64(281)$ & 34 (171) & $162(214)$ & $51(291)$ & $6(171)$ & 17 (192) & $71(195)$ & $1(195)$ & 5 (199) & $16(283)$ & $10(162)$ \\
\hline & Ziyang & $39(192)$ & $33(137)$ & $164(298)$ & $63(176)$ & $7(120)$ & $19(181)$ & $73(155)$ & $1(298)$ & $6(176)$ & 18 (203) & $9(126)$ \\
\hline $\mathrm{R} 4$ & Chengdu & $16(232)$ & $23(225)$ & 86 (267) & $250(327)$ & 4 (139) & $11(267)$ & $63(151)$ & $1(166)$ & 7 (132) & $16(228)$ & $9(101)$ \\
\hline
\end{tabular}

${ }^{\mathrm{a}}$ Others includes initial and boundary conditions, windblown dust, and sea salt. ${ }^{\mathrm{b}}$ Includes the city center of Chongqing. 


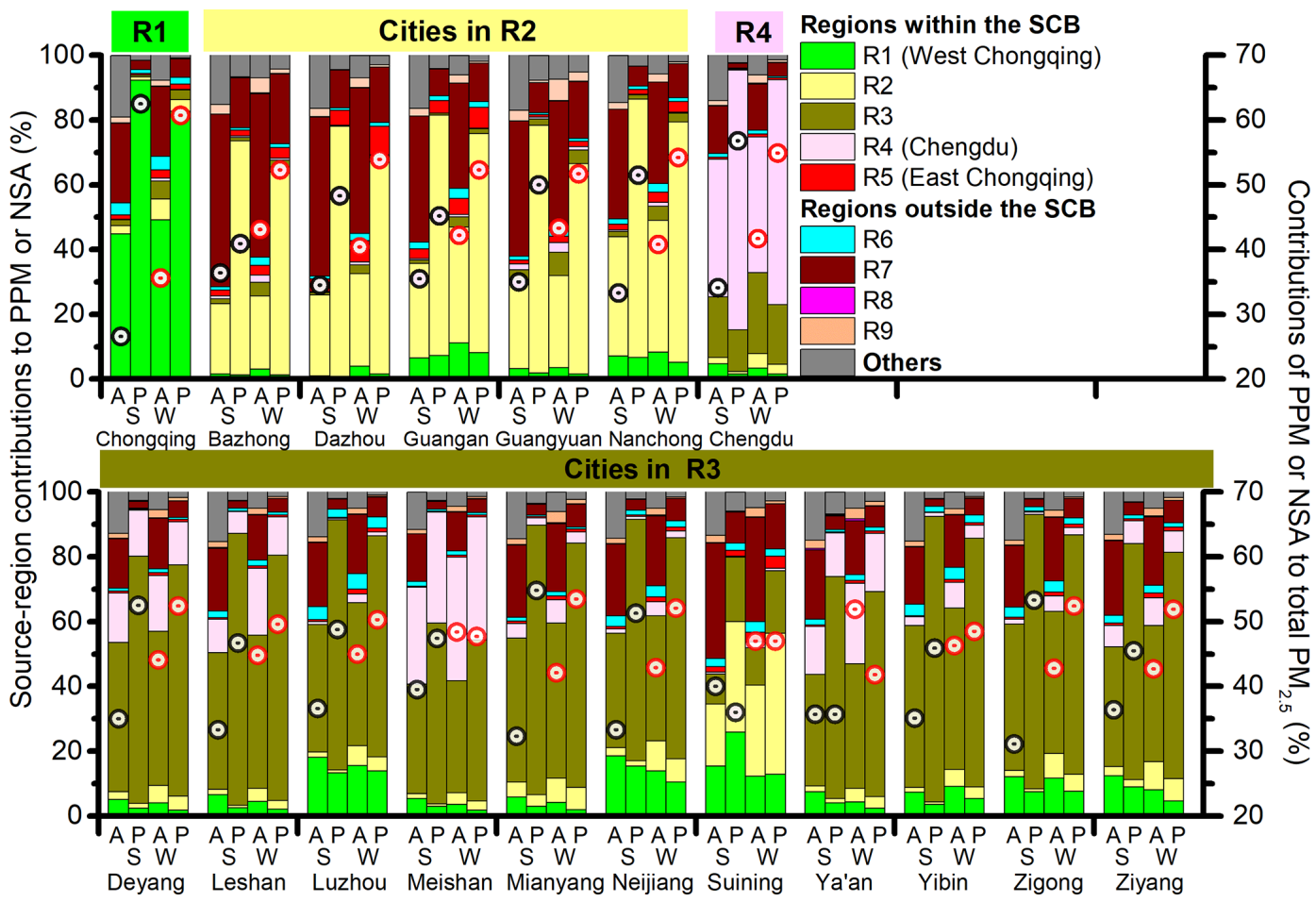

Figure 4. Predicted source-region contributions to SIA (A) and PPM (P) (bars, left $y$ axis) and the predicted proportions of SIA and PPM in $\mathrm{PM}_{2.5}$ (circles, right $y$ axis) for the 18 city centers of the SCB in the summer (S) and winter (W). Others includes IC, BC, windblown dust, and sea salt.

\subsection{Maximum daily contributions from a given region}

The maximum daily contribution from a given region to $\mathrm{PM}_{2.5}$ (MDC, $\mu \mathrm{g} \mathrm{m}^{-3}$ ) in each city center is shown in Table 3 for winter and Table S5 for summer. The largest MDC for each city center (79-291 and 13-147 $\mu \mathrm{g} \mathrm{m}^{-3}$ in the winter and summer, respectively) are found to be associated with local emissions, except for Guangyuan and Suining. In Guangyuan and Suining, the largest MDCs in the winter are from R7 $\left(62 \mu \mathrm{g} \mathrm{m}^{-3}\right)$ and R2 $\left(110 \mu \mathrm{g} \mathrm{m}^{-3}\right)$, both are slightly higher than that from the local region of 60 and $105 \mu \mathrm{g} \mathrm{m}^{-3}$, respectively. Table 3 also shows that the interbasin transport of air pollutants can have large contributions $\left(>50 \mu \mathrm{g} \mathrm{m}^{-3}\right.$ ) on high $\mathrm{PM}_{2.5}$ days $\left(>150 \mu \mathrm{g} \mathrm{m}^{-3}\right)$. For example, R7 contributes $99 \mu \mathrm{g} \mathrm{m}^{-3}$ to total $\mathrm{PM}_{2.5}\left(200 \mu \mathrm{g} \mathrm{m}^{-3}\right)$ in Chongqing on a winter day. In Nanchong, the MDC due to western Chongqing (R1) is $58 \mu \mathrm{g} \mathrm{m}^{-3}$, when daily $\mathrm{PM}_{2.5}$ is $180 \mu \mathrm{g} \mathrm{m}^{-3}$ on that day. In Chengdu, R3 and R7 can contribute up to 86 and $63 \mu \mathrm{g} \mathrm{m}^{-3}$ on the days with daily $\mathrm{PM}_{2.5}$ of 267 and $151 \mu \mathrm{g} \mathrm{m}^{-3}$, respectively. In Deyang and Meishan, the MDCs from Chengdu are 147 and $138 \mu \mathrm{g} \mathrm{m}^{-3}$ on the days that have daily $\mathrm{PM}_{2.5}$ of 288 and $235 \mu \mathrm{g} \mathrm{m}^{-3}$, respectively. Table S4 shows that air pollutant regional transport is also significant on certain days in the summer. For example, the highest summer MDC from R7 among the 18 central cities is found for Bazhong $\left(36 \mu \mathrm{g} \mathrm{m}^{-3}\right)$, when daily $\mathrm{PM}_{2.5}$ is $63 \mu \mathrm{g} \mathrm{m}^{-3}$. Chengdu contributes about $44,16,55,13,7$, and $21 \mathrm{\mu g} \mathrm{m}^{-3}$ to Deyang, Leshan, Meishan, Ya' an, and Mianyang on the summer days, when daily $\mathrm{PM}_{2.5}$ are 89, 56, $100,85,22$, and $54 \mu \mathrm{g} \mathrm{m}^{-3}$, respectively. All the above suggest that joint effects should be made by neighboring cities and the provinces to the east of the SCB in order to prevent high $\mathrm{PM}_{2.5}$ episodes for the SCB.

\subsection{Impacts of topography on $\mathbf{P M}_{2.5}$ concentrations}

While air pollutant emissions are the root of air pollution, topography and meteorological conditions play a very important role in determining the fate of pollutants including dispersion, accumulation, and transformation (Arya, 1999; Zhang et al., 2015; He et al., 2017). It has been widely noticed that heavy air pollution often occurs in well-urbanized and/or industrialized cities associated with mountains and basins, such as Beijing, Chengdu, Xi' an, and Lanzhou in China (Chambers et al., 2015; Bei et al., 2017, 2018; Ning et al., 2018a, b); Mexico City, Salt Lake City, and Los Angeles in the North America (Langford et al., 2010; Whiteman et al., 2014; Calderón-Garcidueñas et al., 2015); and megacities in the Mediterranean Basin of the Europe (Kanakidou et al., 2011). The SCB is surrounded by the QTP to the west, YGP to the south, WUM to the east, and DBM to the northeast. Mainly affected by the high elevations of the QTP and YGP, near-surface winds mainly intrude the basin from the north, east, and southeast in the summer and winter, as 
shown in Figs. 2a and 3a. Consequently, R7 is the largest contributor outside the basin, contributing $20 \%-60 \%$ of $\mathrm{PM}_{2.5}$ in the eastern, northeastern, and southeastern parts of the SCB (Figs. $2 \mathrm{~h}$ and $3 \mathrm{~h}$ ), where $\mathrm{PM}_{2.5}$ concentrations are relatively low in the SCB $\left(<75\right.$ and $25 \mu \mathrm{g} \mathrm{m}^{-3}$ in the winter and summer, respectively). The contributions from R6 (including YGP) and R8 (including QTP) are $<10 \%$ along the western and southern rims of the SCB. Within the basin, near-surface winds travel anticlockwise and form a cyclone near Yibin, Zigong, Neijiang, and Luzhou in the south (Figs. 1b, 2a, and 3a) (Lin, 2015), causing air pollutants transported to be accumulated within the cyclone. $\mathrm{PM}_{2.5}$ concentrations in the cyclone-affected region (mostly $100-150$ and $30-50 \mu \mathrm{g} \mathrm{m}^{-3}$ in the winter and summer, respectively) are generally lower than those of Chengdu and Chongqing but are higher than those of most of the other regions. In Yibin, Zigong, Neijiang, and Luzhou at least $39 \%-53 \%$ and $25 \%-44 \%$ of citywide average $\mathrm{PM}_{2.5}$ concentrations are not due to their own emissions in the winter and summer, respectively (Tables 2 and S2). R7 only contributes about $10 \%$ to $\mathrm{PM}_{2.5}$ in the cyclone-affected region. In order to reduce seasonal and annual concentrations of $\mathrm{PM}_{2.5}$ within the $\mathrm{SCB}$, the emissions and intercity transport of air pollutants within the basin should be prioritized for being controlled.

\section{Conclusions}

In this study, a source-oriented CMAQ model was applied to quantify contributions of nine regions to $\mathrm{PM}_{2.5}$ for the 18 cities in the SCB. The simulations were carried out for winter (December 2014 to February 2015) and summer (June to August 2015). Predicted citywide area-weighted average $\mathrm{PM}_{2.5}$ concentrations are much higher in the winter $(60$ $191 \mu \mathrm{g} \mathrm{m}^{-3}$ ) than in the summer $\left(14-64 \mu \mathrm{g} \mathrm{m}^{-3}\right)$. In the winter, the citywide average $\mathrm{PM}_{2.5}$ concentrations in Chengdu and western Chongqing are 99 and $110 \mu \mathrm{g} \mathrm{m}^{-3}$, with $44 \%$ and $52 \%$ due to nonlocal emissions, respectively. Nonlocal emissions also have high contributions in other SCB cities, with citywide averages of $39 \%-66 \%$ and $25 \%-52 \%$ in the winter and summer, respectively. Among the four regions outside the SCB, only the one to the northeast, east, and southeast of the SCB (R7) has large contributions to $\mathrm{PM}_{2.5}$ concentrations for the SCB in both seasons (10\%-80\%), and the contributions decrease from the rims of the northeastern, eastern, and southeastern SCB to other regions. However, the MDCs from R7 are large (35-99 $\mu \mathrm{g} \mathrm{m}^{-3}$ ) for all the city centers in the winter. On high $\mathrm{PM}_{2.5}$ days in the winter, emissions outside SCB can contribute up to $99 \mu \mathrm{g} \mathrm{m}^{-3}$ in the city center, suggesting the importance of regional emission control in not just reducing averaged $\mathrm{PM}_{2.5}$ but also preventing severe PM pollution events. The transport of SIA and its precursors is greater than that of PPM, suggested by the fact that local emissions have higher contributions to PPM $(>55 \%)$ than to SIA $(<45 \%)$ in the city centers in both sea- sons. Among the three ions of SIA, the transport of $\mathrm{SO}_{4}^{2-}$ and its gas-phase precursor $\left(\mathrm{SO}_{2}\right)$ is the greatest in general, as $>50 \%$ of it in all the city centers is associated with nonlocal emissions in both seasons, except that the contributions are $37 \%-44 \%$ in Chongqing and Chengdu in the summer and Chongqing in the winter. In conclusion, in order to reduce $\mathrm{PM}_{2.5}$ concentrations and prevent high $\mathrm{PM}_{2.5}$ days for the entire SCB, local emissions and the transport of air pollutants within and across SCB should be controlled simultaneously.

Data availability. Hourly modeling results of all the domains are not available online yet because we are using the data for two other studies. We are using hourly modeling data of $\mathrm{PM}_{2.5}, \mathrm{PM}_{10}, \mathrm{SO}_{2}$, $\mathrm{NO}_{2}, \mathrm{O}_{3}$, and $\mathrm{CO}$ to characterize air pollution for the entire basin. The results will be published in Qiao et al. (2019). We are using hourly source apportionment data to quantify the risks from different regions and sectors to human health through $\mathrm{PM}_{2.5}$ pollution. All of the modeling results will be available online after we publish the paper.

Supplement. The supplement related to this article is available online at: https://doi.org/10.5194/acp-19-5791-2019-supplement.

Author contributions. XQ, YT, and HZ designed research. HG, JH, QY, and HZ contributed to model development and configuration. XQ, HG, PW, WD, and XZ analyzed the data. XQ prepared the manuscript and all coauthors helped improve the manuscript.

Competing interests. The authors declare that they have no conflict of interest.

Special issue statement. This article is part of the special issue "Regional transport and transformation of air pollution in eastern China". It does not belong to a conference.

Acknowledgements. Portions of this research were conducted with high-performance computing resources provided by Louisiana State University (http://www.hpc.lsu.edu, last access: 28 April 2019). This study is sponsored by the International Collaboration Project of the Science \& Technology Department of Sichuan Province [2017HH0048], the National Natural Science Foundation of China [41628102], the Program of Introducing Talents of Discipline to Universities [B08037], $\mathrm{PM}_{2.5}$ monitoring in the campuses of Sichuan University [SCU2015CC0001], and the Chinese Scholarship Council [201706245007].

Review statement. This paper was edited by Yuan Wang and reviewed by three anonymous referees. 


\section{References}

Arya, S. P.: Air pollution meteorology and dispersion, Oxford University Press, New York, United States, 1999.

Begum, B. A., Kim, E., Jeong, C.-H., Lee, D. W., and Hopke, P. K.: Evaluation of the potential source contribution function using the 2002 Quebec forest fire episode, Atmos. Environ., 39, 37193724, 2005.

Bei, N. F., Zhao, L. N., Xiao, B., Meng, N., and Feng, T.: Impacts of local circulations on the wintertime air pollution in the Guanzhong Basin, China, Sci. Total Environ., 592, 373-390, 2017.

Bei, N. F., Zhao, L. N., Wu, J. R.,Li, X., Feng, T., and Li, G. H.: Impacts of sea-land and mountain-valley circulations on the air pollution in Beijing-Tianjin-Hebei (BTH): A case study, Environ. Pollut., 234, 429-438, 2018.

Bove, M., Brotto, P., Cassola, F., Cuccia, E., Massabò, D., Mazzino, A., Piazzalunga, A., and Prati, P.: An integrated $\mathrm{PM}_{2.5}$ source apportionment study: positive matrix factorisation vs. the chemical transport model CAMx, Atmos. Environ., 94, 274-286, 2014.

Burr, M. J. and Zhang, Y.: Source apportionment of fine particulate matter over the Eastern U.S. Part I: source sensitivity simulations using CMAQ with the Brute Force method, Atmos. Pollut. Res., 2, 300-317, https://doi.org/10.5094/APR.2011.036, 2011.

Calderón-Garcidueñas, L., Kulesza, R. J., Doty, R. L., D’Angiulli, A., and Torres-Jardón, R.: Megacities air pollution problems: Mexico City Metropolitan Area critical issues on the central nervous system pediatric impact, Environ. Res., 137, 157-169, 2015.

Chambers, S. D., Wang, F., Williams, A. G., Deng, X. D., Zhang,H., Lonati, G., Crawford, J., Griffiths, A. D., Lanniello, A., and Allegrini, I.: Quantifying the influences of atmospheric stability on air pollution in Lanzhou, China, using a radon-based stability monitor, Atmos. Environ., 107, 233-243, 2015.

Chen, D., Liu, X., Lang, J., Zhou, Y., Wei, L., Wang, $\mathrm{X}$., and Guo, X.: Estimating the contribution of regional transport to $\mathrm{PM}_{2.5}$ air pollution in a rural area on the North China Plain, Sci. Total Environ., 583, 280-291, https://doi.org/10.1016/j.scitotenv.2017.01.066, 2017.

Chen, Y. and Xie, S.: Characteristics and formation mechanism of a heavy air pollution episode caused by biomass burning in Chengdu, Southwest China, Sci. Total Environ., 473-474, 507517, https://doi.org/10.1016/j.scitotenv.2013.12.069, 2014.

Chen, Y., Luo, B., and Xie, S.: Characteristics of the long-range transport dust events in Chengdu, Southwest China, Atmos. Environ., 122, 713-722, 2015.

Crippa, M., Guizzardi, D., Muntean, M., Schaaf, E., Dentener, F., van Aardenne, J. A., Monni, S., Doering, U., Olivier, J. G. J., Pagliari, V., and Janssens-Maenhout, G.: Gridded emissions of air pollutants for the period 1970-2012 within EDGAR v4.3.2, Earth Syst. Sci. Data, 10, 1987-2013, https://doi.org/10.5194/essd-10-1987-2018, 2018.

Emery, C., Tai, E., and Yarwood, G.: Enhanced meteorological modeling and performance evaluation for two Texas ozone episodes, Final report submitted to Texas natural resources conservation commission, prepared by ENVIRON, International Corp., Novato, 2001.

Emery, C., Liu, Z., Russell, A. G., Odman, M. T., Yarwood, G., and Kumar, N.: Recommendations on statistics and benchmarks to assess photochemical model performance, J. Air Waste Manage., 67, 582-598, 2017.

Guenther, A. B., Jiang, X., Heald, C. L., Sakulyanontvittaya, T., Duhl, T., Emmons, L. K., and Wang, X.: The Model of Emissions of Gases and Aerosols from Nature version 2.1 (MEGAN2.1): an extended and updated framework for modeling biogenic emissions, Geosci. Model Dev., 5, 1471-1492, https://doi.org/10.5194/gmd-5-1471-2012, 2012.

Han, X., Zhu, L., Wang, S., Meng, X., Zhang, M., and Hu, J.: Modeling study of impacts on surface ozone of regional transport and emissions reductions over North China Plain in summer 2015, Atmos. Chem. Phys., 18, 12207-12221, https://doi.org/10.5194/acp-18-12207-2018, 2018.

He, J., Gong, S., Yu, Y., Yu, L. J., Wu, L., Mao, H. J., Song, C. B., Zhao, S. P., Liu, H. L., Li, X. Y., and Li, R. P.: Air pollution characteristics and their relation to meteorological conditions during 2014-2015 in major Chinese cities, Environ. Pollut., 223, 484496, 2017.

Hopke, P. K.: Review of receptor modeling methods for source apportionment, J. Air Waste Manage., 66, 237-259, 2016.

Hu, J., Wu, L., Zheng, B., Zhang, Q., He, K., Chang, Q., Li, X., Yang, F., Ying, Q., and Zhang, H.: Source contributions and regional transport of primary particulate matter in China, Environ. Pollut., 207, 31-42, 2015.

Huang, R. J., Zhang, Y. L., Bozzetti, C., Ho, K. F. Cao, J. J., Han, Y. M., Daellenbach, K. R., Slowik, J. G., Platt, S. M., Canonaco, F., Zotter, P., Wolf, R., Pieber, S. M., Bruns, E. A., Crippa, M., Ciarelli, G., Pizaazlunga, A., Schwikowski, M., Abbaszade, G., Schnelle-Kreis, J., Zimmermann, R., An, Z. S., Szidat, S., Baltensperger, U., Haddad, I. E., and Prévôt, A. H.: High secondary aerosol contribution to particulate pollution during haze events in China, Nature, 514, 218-222, 2014.

Huang, Y., Deng, T., Li, Z., Wang, N., Yin, C., Wang, S., and Fan, S.: Numerical simulations for the sources apportionment and control strategies of $\mathrm{PM}_{2.5}$ over Pearl River Delta, China, part I: Inventory and $\mathrm{PM}_{2.5}$ sources apportionment, Sci. Total Environ., 634, 1631-1644, https://doi.org/10.1016/j.scitotenv.2018.04.208, 2018.

Itahashi, S., Hayami, H., Yumimoto, K., and Uno, I.: Chinese province-scale source apportionments for sulfate aerosol in 2005 evaluated by the tagged tracer method, Environ. Pollut., 220, 1366-1375, 2017.

Jiang, C., Wang, H., Zhao, T., Li, T., and Che, H.: Modeling study of PM2.5 pollutant transport across cities in China's Jing-JinJi region during a severe haze episode in December 2013, Atmos. Chem. Phys., 15, 5803-5814, https://doi.org/10.5194/acp15-5803-2015, 2015.

Kanakidou, M., Mihalopoulos, N., Kindap, T., Im, U., Vrekoussis, M., Gerasopoulos, E., Dermitzaki, E., Unal, A., Koçak, M., Kostas, M., Melas, D., Kouvarakis, G., Youssef, A. F., Richter, A., Hatzianastassiou, N., Hiboll, A., Ebojie, F., Wittrock, F., Savigny, C. V., Burrows, J. P., Ladstaetter-Weissenmayer, A., and Moubasher, H.: Megacities as hot spots of air pollution in the East Mediterranean, Atmos. Environ., 45, 1223-1235, 2011.

Kang, Y., Liu, M., Song, Y., Huang, X., Yao, H., Cai, X., Zhang, H., Kang, L., Liu, X., Yan, X., He, H., Zhang, Q., Shao, M., and Zhu, T.: High-resolution ammonia emissions inventories in China from 1980 to 2012, Atmos. Chem. Phys., 16, 2043-2058, https://doi.org/10.5194/acp-16-2043-2016, 2016. 
Kim, P. S., Jacob, D. J., Fisher, J. A., Travis, K., Yu, K., Zhu, L., Yantosca, R. M., Sulprizio, M. P., Jimenez, J. L., CampuzanoJost, P., Froyd, K. D., Liao, J., Hair, J. W., Fenn, M. A., Butler, C. F., Wagner, N. L., Gordon, T. D., Welti, A., Wennberg, P. O., Crounse, J. D., St. Clair, J. M., Teng, A. P., Millet, D. B., Schwarz, J. P., Markovic, M. Z., and Perring, A. E.: Sources, seasonality, and trends of southeast US aerosol: an integrated analysis of surface, aircraft, and satellite observations with the GEOS-Chem chemical transport model, Atmos. Chem. Phys., 15, 10411-10433, https://doi.org/10.5194/acp-15-104112015, 2015.

Langford, A. O., Senff, C. J., Alvarez II, R. J., Banta, R. M., and Hardesty, R. M.: Long-range transport of ozone from the Los Angeles Basin: A case study, Geophys. Res. Lett., 37, L06807, https://doi.org/10.1029/2010GL042507, 2010.

Lelieveld, J., Evans, J. S., Fnais, M., Giannadaki, D., and Pozzer, A.: The contribution of outdoor air pollution sources to premature mortality on a global scale, Nature, 525, 367-371, 2015.

Li, L., Tan, Q., Zhang, Y., Feng, M., Qu, Y., An, J., and Liu, X.: Characteristics and source apportionment of $\mathrm{PM}_{2.5}$ during persistent extreme haze events in Chengdu, southwest China, Environ. Pollut., 230, 718-729, 2017.

Li, P., Yan, R., Yu, S., Wang, S., Liu, W., and Bao, H.: Reinstate regional transport of $\mathrm{PM}_{2.5}$ as a major cause of severe haze in Beijing, P. Natl. Acad. Sci. USA, 112, E2739-E2740, 2015.

Lin, N.: The research on transport law of atmospheric pollutant and joint prevention and control of air pollution technology in Sichuan Province, Southwest Jiaotong University, Chengdu, China, 2015.

Liao, T., Wang, S., Ai, J., Gui, K., Duan, B., Zhao, Q., Zhang, X., Jiang, W., and Sun, Y.: Heavy pollution episodes, transport pathways and potential sources of $\mathrm{PM}_{2.5}$ during the winter of 2013 in Chengdu (China), Sci. Total Environ., 584, 1056-1065, 2017.

Liu, S., Hua, S., Wang, K., Qiu, P., Liu, H., Wu, B., Shao, P., Liu, X., $\mathrm{Wu}, \mathrm{Y}$., and Xue, Y.: Spatial-temporal variation characteristics of air pollution in Henan of China: Localized emission inventory, WRF/Chem simulations and potential source contribution analysis, Sci. Total Environ., 624, 396-406, 2018.

National Bureau of Statistics (NSBC): China Statistics Yearbook, available at: http://www.stats.gov.cn/tjsj/ndsj/2016/indexch.htm (last access: 28 April 2019), 2015.

Ning, G., Wang, S., Ma, M., Ni, C., Shang, Z., Wang, J., and Li, J.: Characteristics of air pollution in different zones of Sichuan Basin, China, Sci. Total Environ., 612, 975-984, 2018a.

Ning, G., Wang, S., Yim, S. H. L., Li, J., Hu, Y., Shang, Z., Wang, J., and Wang, J.: Impact of low-pressure systems on winter heavy air pollution in the northwest Sichuan Basin, China, Atmos. Chem. Phys., 18, 13601-13615, https://doi.org/10.5194/acp-18-136012018, 2018b.

Paatero, P. and Tapper, U.: Positive matrix factorization: A nonnegative factor model with optimal utilization of error estimates of data values, Environmetrics, 5, 111-126, 1994.

Qiao, X., Ying, Q., Li, X. H., Zhang, H. L., Hu, J. L., Tang, Y., and Chen X.: Source apportionment of $\mathrm{PM}_{2.5}$ for 25 Chinese provincial capitals and municipalities using a source-oriented community multiscale air quality model, Sci. Total Environ., 612, 462471, 2018

Qiao, X., Guo, H., Wang, P. F., Tang, Y., Ying, Q., Zhao, X., Deng, W. Y., and Zhang, H. L.: Modeling Fine Particulate Matter and
Ozone in the 18 Cities of Sichuan Basin, Southwestern China, in preparation, 2019.

Qiu, Y. M., Xie, Q. R., Wang, J. F., Xu, W. Q., Li, L. J., Wang, Q. Q., Zhao, J., Chen, Y. T., Chen, Y. F., Wu, Y. Z., Du, W., ZHou, W., Lee, J., Zhao, C. F., Ge, X. L., Fu, P. Q., Wang, Z. F., Worsnop, D. R., and Sun, Y. L.: Vertical characterization and source apportionment of water-soluble organic aerosol with high-resolution aerosol mass spectrometry in Beijing, China, ACS Earth Space Chem., 3, 273-284, 2019.

Shi, X. Q., Zhao, C. F., Jiang, J. H., Wang, C. Y., Yang, X., and Yung, Y. L.: Spatial representativeness of $\mathrm{PM}_{2.5}$ concentrations obtained using observations from network stations, J. Geophys. Res.-Atmos., 123, 3145-3158, 2018.

Shi, Z., Li, J., Huang, L., Wang, P., Wu, L., Ying, Q., Zhang, H., Lu, L., Liu, X., Liao, H., and Hu, J.: Source apportionment of fine particulate matter in China in 2013 using a source-oriented chemical transport model, Sci. Total Environ., 601-602, 14761487, https://doi.org/10.1016/j.scitotenv.2017.06.019, 2017.

Stein, A., Draxler, R. R., Rolph, G. D., Stunder, B. J., Cohen, M., and Ngan, F.: NOAA's HYSPLIT atmospheric transport and dispersion modeling system, B. Am. Meteorol. Soc., 96, 20592077, 2015.

Tang, L., Yu, H., Ding, A., Zhang, Y., Qin, W., Wang, Z., Chen, W., Hua, Y., and Yang, X.: Regional contribution to $\mathrm{PM}_{1}$ pollution during winter haze in Yangtze River Delta, China, Sci. Total Environ., 541, 161-166, 2016.

Tao, J., Zhang, L., Engling, G., Zhang, R., Yang, Y., Cao, J., Zhu, C., Wang, Q., and Luo, L.: Chemical composition of $\mathrm{PM}_{2.5}$ in an urban environment in Chengdu, China: Importance of springtime dust storms and biomass burning, Atmos. Res., 122, 270-283, 2013.

Uno, I., Eguchi, K., Yumimoto, K., Takemura, T., Shimizu, A., Uematsu, M., Liu, Z., Wang, Z., Hara, Y., and Sugimoto, N.: Asian dust transported one full circuit around the globe, Nat. Geosci., 2, 557-560, 2009.

Wang, L., Jang, C., Zhang, Y., Wang, K., Zhang, Q., Streets, D., Fu, J., Lei, Y., Schreifels, J., He, K., Hao, J., Lam, Y. F., Lin, J., Meskhidze, N., Voorhees, S., Evarts, D., and Phillips, S.: Assessment of air quality benefits from national air pollution control policies in China. Part I: Background, emission scenarios and evaluation of meteorological predictions, Atmos. Environ., 44, 3442-3448, https://doi.org/10.1016/j.atmosenv.2010.05.051, 2010.

Wang, L. T., Wei, Z., Yang, J., Zhang, Y., Zhang, F. F., Su, J., Meng, C. C., and Zhang, Q.: The 2013 severe haze over southern Hebei, China: model evaluation, source apportionment, and policy implications, Atmos. Chem. Phys., 14, 3151-3173, https://doi.org/10.5194/acp-14-3151-2014, 2014.

Wang, M., Cao, C., Li, G., and Singh, R.: Analysis of a severe prolonged regional haze episode in the Yangtze River Delta, China, Atmos. Environ., 102, 112-121, 2015.

Wang, Z. S., Chao-Jung, C., and Tonnesen, G. S.: Development of a tagged species source apportionment algorithm to characterize three-dimensional transport and transformation of precursors and secondary pollutants, J. Geophys. Res.-Atmos., 114, D21206, https://doi.org/10.1029/2008JD010846, 2009.

Watson, J. G., Robinson, N. F., Chow, J. C., Henry, R. C., Kim, B., Pace, T., Meyer, E. L., and Nguyen, Q.: The USEPA/DRI chem- 
ical mass balance receptor model, CMB 7.0, Environ. Softw., 5, 38-49, 1990.

Whiteman, C. D., Hoch, S. W., Horel, J. D., and Charland, A.: Relationship between particulate air pollution and meteorological variables in Utah's Salt Lake Valley, Atmos. Environ., 94, 742753, 2014.

WHO: WHO air quality guidelines for particulate matter, ozone, nitrogen dioxide and sulfur dioxide, available at: https://apps.who.int/iris/bitstream/handle/10665/69477/WHO_

SDE_PHE_OEH_06.02_eng.pdf;sequence=1 (last access: 28 April 2019), 2006.

Wiedinmyer, C., Akagi, S. K., Yokelson, R. J., Emmons, L. K., AlSaadi, J. A., Orlando, J. J., and Soja, A. J.: The Fire INventory from NCAR (FINN): a high resolution global model to estimate the emissions from open burning, Geosci. Model Dev., 4, 625641, https://doi.org/10.5194/gmd-4-625-2011, 2011.

Wu, Y., Arapi, A., Huang, J., Gross, B., and Moshary, F.: Intracontinental wildfire smoke transport and impact on local air quality observed by ground-based and satellite remote sensing in New York City, Atmos. Environ., 187, 266-281, 2018.

Yang, X., Zhao, C., Zhou, L., Li, Z., Cribb, M., and Yang, S.: Wintertime cooling and a potential connection with transported aerosols in Hong Kong during recent decades, Atmos. Res., 211, 52-61, 2018.

Ying, Q., Wu, L., and Zhang, H.: Local and inter-regional contributions to $\mathrm{PM}_{2.5}$ nitrate and sulfate in China, Atmos. Environ., 94, 582-592, https://doi.org/10.1016/j.atmosenv.2014.05.078, 2014.

Zhang, H. L., Wang, Y., Hu, J. L., Ying, Q., and Hu, X. M.: Relationships between meteorological parameters and criteria air pollutants in three megacities in China, Environ. Res., 140, 242254, 2015.

Zhang, R., Jing, J., Tao, J., Hsu, S.-C., Wang, G., Cao, J., Lee, C. S. L., Zhu, L., Chen, Z., Zhao, Y., and Shen, Z.: Chemical characterization and source apportionment of $\mathrm{PM}_{2.5}$ in Beijing: seasonal perspective, Atmos. Chem. Phys., 13, 7053-7074, https://doi.org/10.5194/acp-13-7053-2013, 2013.

Zhao, B., Wang, S., Dong, X., Wang, J., Duan, L., Fu, X., Hao, J., and Fu, J.: Environmental effects of the recent emission changes in China: implications for particulate matter pollution and soil acidification, Environ. Res. Lett., 8, 024031, https://doi.org/10.1088/1748-9326/8/2/024031, 2013.
Zhao, C., Andrews, A. E., Bianco, L., Eluszkiewicz, J., Hirsch, A., MacDonald, C., Nehrkorn, T., and Fischer, M. L.: Atmospheric inverse estimates of methane emissions from Central California, J. Geophys. Res.-Atmos., 114, https://doi.org/10.1029/2008JD011671, 2009.

Zhao, C. F., Li, Y. N., Zhang, F., Sun, Y. L., and Wang, P. C.: Growth rates of fine aerosal particles at a site near Beijing in June 2013, Adv. Atmos. Sci., 35, 209-217, 2018.

Zhao, C. F., Wang, Y., Shi, X. Q., Zhang, D. Z., Wang, C. Y., Jiang, J. H., Zhang, Q., and Fan, H.: Estimating the contribution of local primary emissions to particulate pollution using high-density station observations, J. Geophys. Res.-Atmos., 124, https://doi.org/10.1029/2018JD028888, 2019.

Zhao, Q., He, K., Rahn, K. A., Ma, Y., Jia, Y., Yang, F., Duan, F., Lei, Y., G, Chen, Cheng, Y., H, Liu, and Wang, S.: Dust storms come to Central and Southwestern China, too: implications from a major dust event in Chongqing, Atmos. Chem. Phys., 10, 26152630, https://doi.org/10.5194/acp-10-2615-2010, 2010.

Zhao, S., Yu, Y., Yin, D., Qin, D., He, J., and Dong, L.: Spatial patterns and temporal variations of six criteria air pollutants during 2015 to 2017 in the city clusters of Sichuan Basin, China, Sci. Total Environ., 624, 540-557, 2018.

Zhao, X., Zhao, P., Xu, J., Meng, W., Pu, W., Dong, F., He, D., and Shi, Q.: Analysis of a winter regional haze event and its formation mechanism in the North China Plain, Atmos. Chem. Phys., 13, 5685-5696, 2013.

Zheng, G. J., Duan, F. K., Su, H., Ma, Y. L., Cheng, Y., Zheng, B., Zhang, Q., Huang, T., Kimoto, T., Chang, D., Pöschl, U., Cheng, Y. F., and He, K. B.: Exploring the severe winter haze in Beijing: the impact of synoptic weather, regional transport and heterogeneous reactions, Atmos. Chem. Phys., 15, 2969-2983, https://doi.org/10.5194/acp-15-2969-2015, 2015.

Zhu, Y., Huang, L., Li, J., Ying, Q., Zhang, H., Liu, X., Liao, H., Li, N., Liu, Z., and Mao, Y.: Sources of particulate matter in China: Insights from source apportionment studies published in 19872017, Environ. Int., 115, 343-357, 2018. 